\title{
An Anti-social Socialist: A Critical Reading of Arthur Miller's Death of a Salesman
}

\author{
Kaveh Khodambashi Emami \\ ACECR, Isfahan University of Technology, Isfahan, Iran \\ Email:kavehkhodambashi@yahoo.co.uk
}

\begin{abstract}
For long Arthur Miller and his plays were praised (especially by Marxist critics) as strong critics of capitalist societies and their dehumanizing force upon individuals living in them. Using Frankfurth school's views, Miller's own ideas and his play Death of a Salesman, this paper reveals some faults and contradictions in characterization, plot and other aspects of the play that would question Miller's opposition against capitalism and his criticism of it.
\end{abstract}

Index Terms - Death of a Salesman, Capitalism, high culture, Marxism, popular culture, social play

\section{INTRODUCTION}

In his plays Miller has dealt mostly with the social issues of his day and this is the case with Death of a Salesman too. It is probably this characteristic that caused Death of a Salesman to be the center for much critical debate as to what it signifies, right from the beginning. Among those who so much celebrated the play were critics with a Marxist line of thought. They perceived it as a "social play", an attack upon, or a criticism of society and its system of beliefs, knowing Willy Loman (the major character of the play) to be flawless. They also labeled Miller as a true social writer who is critical of capitalist society and its values (Finkelstein, 1967) (Gassner, 1954) (Lewis, 1970). On the other hand, there appeared a growing trend among many of those who approached this play to condemn Willy Loman out of hand, believing his actions to be the root of his destruction and knowing society to be free of any guilt (Corrigan, 1969) (Carson, 1982) (Downer, 1967) (Lumley, 1967). Though personally I find the arguments put forward by the former group stronger and more valuable there are some points which I think left unnoticed by these critics which make them unable to account for some of the seemingly contradictory aspects of the play. The major task of the present paper is to analyze the play with the help of Marxist literary criticism but in a way that enables us to solve all the doubts and contradictions of the play and finally to answer the question of whether we can call it a "social play" (as celebrated by most of the Marxist critics) or not.

To do so it is most helpful first to grasp some ideas about literature and social criticism, the way a writer deals with social matters and how important his social and political views can be in shaping his works from Marxist point of view. Even those only slightly acquainted with the Marxist criticism know that what it wants from a writer is to commit his art to the cause of the proletariat. The principle doctrine related to this topic was called "Proletkult". The doctrine states that "Literature must be tendentious, party minded, optimistic and heroic; it should be infused with a revolutionary romanticism, portraying heroes and prefiguring the future" (Eagleton, 2001, p.35). In this regard there is Marx's view about the relation between a writer's social and political views and his writings. Marx says in a criticism of Sue LaSalle's novel, that what it shows diverges from what it says. He adds that French bourgeois ideology is the dominant ideology in the work and the main force that caused the novel to sell so well, but at the same time the novel can occasionally "reach beyond its ideological limits and deliver a slap in the face of bourgeois prejudice" (Eagleton, 2001, pp.44-45).

As Eagleton argues, according to Luckacs modern writers should do more than "merely reflect the despair and ennui of late bourgeois society; they should try to take up a critical perspective on this futility, revealing positive possibilities beyond it" (Eagleton, 2001, p.48). On the other hand according to Eagleton, if we regard Brecht's ideas about theatre and its role in the society, we see that he believed bourgeois art to be based on illusion. With the help of this illusion it makes people think that what is presented to them is reality itself. The audience in bourgeois theatre is "the passive consumer of a finished, unchangeable art object offered to them as real" (Eagleton, 2001, pp.59-60). The play does not allow the audience to think about how it is made, how it represents its characters and events and in what ways (if there is any) can these characters be different from what they are. Because the dramatic illusion conceals the fact that it is constructed, it prevents an audience from "reflecting critically on both the mode of representation and the actions represented" (Eagleton, 2001, p.62). Brecht recognized that this reflected an ideological belief that the world was fixed, and unchangeable, and that the function of the theatre was "to provide escapist entertainment for men trapped in that assumption" (Eagleton, 2001, p.62). So we see that bourgeois art (which is the dominant form of art according to Brecht) is exactly the opposite of the "Social" art that Marxist writers and critics use to favor and praise. The art that Marxists believed in is the art that is revolutionary, an art which shows the short comings of the bourgeois system and makes the audience react against it and eventually bring about the change required. Regarding the different views discussed above, 
Miller's relationship with his plays, the subject he deals with in them and the way he deals with those subjects can be discussed and analyzed.

\section{ANAlysis OF THE Play}

What Miller asks for is a theater of "heightened consciousness." He speaks of two passions in man, the "passion to feel" and the "passion to know." He believes that we need, and can have, more of the latter in his plays. Miller believes that drama must "help us to know more and not merely to spend our feelings" (Corrigan, 1969, p.61). Elsewhere he says "the end of the drama is the creation of a higher consciousness and not merely a subjective attack upon the audience's nerves and feelings" (Williams, 1971, p.274). This idea is akin to that of Brecht mentioned before. But these prove to be merely ideas since we can hardly find any traces of them in this play. Here a controversial scene would be the final Requiem scene, where Linda, his two sons, and Charley are at Willy's burial ceremony. The way this part is structured and the characters' speeches are formed seems to make it an unnecessary and detached part of the play. Linda's cries and statements or Charley's words that are used to justify Willy's actions have only one function; that is to sell Willy to the audience and to get the maximum tears out of them. There seems to be no reason for the sudden change in the mind of Charley, regarding Willy's ideals. Charley used to criticize Willy for his wrong ideas and values and tried to make him understand that having dreams is of no use, but in the last scene we see him defending Willy by saying that "a salesman has got to dream" (Perrine, , 1974, p.1470). There is hardly anything found in this scene to help to raise the knowledge of the audience about the world they live in and its laws, or explain why Willy's ideas suddenly seems so praiseworthy to Charley. But regarding what has been said, this scene seems to be merely an attack upon the feelings of the reader or the audience. In the concluding paragraphs of his introduction to his collected plays Miller rejects the idea that man is at best the sum of forces (psychological and social) working upon him from within and without and adds that:

Man is more than the sum of his stimuli and is unpredictable beyond a certain point. A drama, like a history, which stops at this point, the point of conditioning, is not reflecting a reality.... If there is one unseen goal toward which every play in this book strives, it is that... we are made and yet more than what made us (Miller, 1967, pp.54-55).

As it is clear Miller believes that man is able to pull his weight in life. This is much quoted by some critics who try to prove that what happens to Willy in his life and his final death are mostly direct outcome of his own choice and society doesn't play much role here. Even Marxist critics, who believe Willy Loman as a victim of society and its values, say that at the end Willy revolts against these values and changes the fate that society had in store for him by committing suicide. To them suicide means rejection of society and its depersonalizing system since what it wants from an individual is to accept his nothingness and to declare (like Biff does) that he is "a dime a dozen" a man with no real human value. Willy doesn't want to accept that the outcome of all the ideas proposed by society is this and by killing himself he tries to prove that he can still have individuality, be loved and remembered. That is why most Marxist critics believe him to be a revolutionary hero who puts under question the capitalistic system of society. But it should be argued that on the contrary Willy as a character has accepted his fate and what the society had in store for him. I agree that what Willy believes in and teaches to his sons are given to him by society but I also believe that at the end when Willy finds out that these values are shallow and nothing more than a lie, he tries to act differently to defy them. But as Charley tells him, in this society which is based on competition, a man's value is measured by how much more he has than the others and the only thing that counts is what one has to sell. As Willy finds out, personality, individuality and being respected and valued as an individual human being regardless of the material gains one has achieved are no more in question in the society. Therefore, as Willy has not achieved any material gains he has no place in the society and must give up his dreams. It is this vision that leads him to suicide since it means he has sold himself for 20000 dollars and that is exactly what society wants him to do because Willy has nothing left to sell in his life other than his life itself. So as could be seen even at the end Willy is defeated and society is the winner. Other characters have also accepted the conditions and terms of the society but they are different from Willy in that they have never questioned it and tried to fit it as best as they could and that is why they have become successful (of course in the eyes of a capitalist society). This is the society that we face in this play and Miller does not show any way out of its futility, there is no hope for a better future for people like Lomans pointed to in the play. Willy kills himself. His two sons, though they have different understanding and view about life, both have an unclear future. Happy who is a follower of his father's way of life is most probably going to have a tragic ending, an ending similar to that of Willy. Though it is difficult to predict the future of Biff, something which the play does not make clear too, but we can say that though he will receive enough money (from his father's life insurance) he will also lead a dreadful life because he has accepted his nothingness and his defeat by the society. This society will allow him to live since he can clearly understand that he is just a "dime a dozen" and nothing more but he will have no personality and dignity which is a characteristic of a real human being. This shows that Miller's play gives us the idea of unchangeability of the society and fate, and in this way he has written a bourgeois theatre rather than a social one. This is certainly not a kind of social play which Marxists like Lukacs, Engels or a revolutionary writer and critic like Brecht had in mind and believed in. Moreover Marxists believed that a true social play portrays heroes, and prefigures a hopeful future, but in this play we see the opposite. Willy, if we can call him a hero at all, is a consenting hero, one who in seeing the uselessness and futility of opposing society, throws away all his ideals and does not rest his hope in the future. Even if he talks of any future it is what the society means by a 
future; that is to be number one and to have more than the others. That is why he hopes that in the future Biff will be better than others in terms of the money he has and says "imagine that magnificence with twenty thousand dollars in his pocket! When the mail comes he will be ahead of Bernard again"(Perrine, 1974 , p.1468). Moreover, neither he nor his actions can be called great or heroic. No hero, no heroic act, and no sign of hope for the future; this is certainly not the kind of social drama that is meant by what were discussed in the beginning of this part.

Despite what many critics believe, Miller's ideas too are not revolutionary, radical and new. Not only he does not propose revolution in his play against the social law and order, but at the end of the play the social order is confirmed. Miller's play does not attempt to startle the society with new ideas. He believes that the theatre should enunciate "ideas which are already in the air, ideas for which there has already been a preparation by non dramatic media" (Corrigan, 1969, p.59). He has from the beginning aimed at a clarification of the already existent attitudes which were prominent among the American theatre goers. His play is largely for and from the point of view of a man whose attitudes is not radical and innovatory but "puzzled", confused, and does not want to break with his fellow countrymen (Corrigan, 1969 p.59). Furthermore, Miller might present Death in "a spirit of puzzled, anguished analysis" (Corrigan, 1969, p.136) but does not suggest that anything like revolutionary change in American society might be necessary. In other words he wants theater to present a balanced concept of life without the questioning author preaching revolution. Consequently, when Willy is betrayed by myths and ethics of his society, all we have and are given by Miller is Linda's pitiful cry that "attention, attention must finally be paid to such a person" (Miller, 1956, p.1421). In this play Miller deals with the themes of faith and meaning within the confused social and personal life in America, and deals with them without producing ideas which might call for a rethinking of the society (Corrigan, 1969, p.136). Speaking about his play All My Sons and Kris Keller's way of thought, Miller once remarked "I cannot live apart from the world" (Brown \& Harris, 1975, p.127) and Death of a Salesman is a dramatization of the way a man gets alienated from his society and then tries to get back to it. Willy cannot live apart from his society too. But in this play the structure of that society goes uncondemned and unanalyzed, taken as if it were unchangeable. The weight of actions falls cruelly on the individual within the fixed, powerful society which fails to support him at his moment of need and remains indifferent, as he falls. Another reason for Miller not to believe in revolutionary change is that he wanted his plays to attract the attention of the audience. Miller had a kind of problem regarding his plays; that is, he was not at ease with the moral and political content of his plays. In "The Playwright and the Atomic World" speaking of the reception of his plays outside America, he notes that Europeans are "more interested in the philosophic, moral and principled values of the play than we are", whereas Americans "create methods of reaching the great mass of the people" (Brown \& Harris, 1975, p.146). Miller wishes to write for the majority audience, and his desire leads him to write plays which have in mind player goers' tastes and social values. To be accepted by the large number of audience he had to ignore those ideas and themes which were unacceptable by them or not interesting to them. And of course those new ideas which put their system of belief and values under question must be avoided as far as possible.

It is worthy of note that Miller believes that the tragic flaw is an "inherent unwillingness to remain passive" (Corrigan, 1969, p.85). The passives are therefore, he concludes, flawless and the majority is passive. It is surely according to this that we see in the play the evil lays in those who disturb their environment actively, Willy Loman being a symbol of them. To blame those who are active and do not accept all that is given or done to them is certainly an anti-socialist way of thought and (to me) it is a crude way of saving society from being challenged and changed. This view can be supported further by paying attention to the part of Miller's essay on Death which is about Willy and his fault. Explaining the reason why he as well as a large number of the audience regard Willy as guilty he says:

The answer I think is not that we respect the man, but that we respect the law that he has so completely broken, wittingly or not, for it is that law which, we believe, defines us as men. The confusion of some critics viewing Death of a Salesman in this regard is that they do not see that Willy Loman has broken a law without whose protection life is insupportable if not incomprehensible to him and to many others; it is the law which says that a failure in society and in business has no right to live. (Miller, 1967, p. 35).

But that is incredible of Miller. It is he who seems to be in confusion since the law which he is talking about is in no way the law which can make our life comprehensible and the lack of which would lead to chaos and incomprehension.

Thus far our discussion mainly dealt with Miller's own ideas and statements but here on it is tried to analyze other aspects of the play in a rather different light by using Adorno's ideas on popular culture and art. In his famous essay, "How to Look at Television", Adorno tries to crystallize a number of theoretical concepts, with the help of which we can study the effect of television and its impact upon the personality of viewers. In this essay a distinction is made by Adorno between high culture and mass culture, and then he compares and contrasts their characteristics with each other. According to him the message which is dominant and "all pervasive" in today's mass culture is the message of obedience and adjustment (Witkin, 2003, p.140). This is also noted by Adorno and Horkheimer in the Dialectics of Enlightenment, where they view modern culture as a training ground for those acts of submission and resignation through which one is promised some kind of survival. They see the products of mass culture as examples of a process in which culture industry repeatedly uses an individual's dependency, helplessness, submission and surrender to the social order, as an "aesthetic object" for demonstration. Films which show people crushed and defeated in normal life, under desperate situations, promise the viewer that if she or he becomes aware of his or her nothingness and accept defeat, 
then "fate and circumstance" will allow she or he to live. Helplessness, submission and defeat are what, according to Adorno, can also be traced in many other spheres of art like Jazz, and Hollywood movies.

All these provide models of submission for those who must become what the society requires them to become. Adorno adds that in mass culture, the outcome of conflicts is pre-established, and all the conflicts are mere sham. Society is always the winner, and the individual is always the puppet "manipulated" through social rules. They teach their readers that one has to be realistic, that one has to give up romantic ideas, that one has to adjust oneself at any price, and that nothing more can be expected from any individual. The conflict between the society and the individual has been vanished and the message is that of identification with the status quo (Witkin, 2003, pp.141-145). Adorno believes that to understand the process in which mass culture influences the individual we have to do a "deep psychological" study focused on the "multilayered structure" of culture industry's different components. Of course, he does his research particularly on television. He says that "mass media are not simply the sum total of the actions they portray or of the messages that radiate from these actions" (Witkin, 2003, p.141). He adds that mass media are made of different layers of meaning which are "superimposed" upon each other and each has its own effect. In mass media, the hidden message may be more important than the overt message, because the hidden message can pierce through the mind of individual and influence his mind without being noticed and restricted by "controls of consciousness" (Witkin, 2003, p.141).

Of course the relation between hidden and overt message is highly complex. For example, a number of repressed desires and ideas which form a great part of the hidden message are manifested by the surface message in "jests, offcolor remarks, suggestive situations, and similar devices" (Witkin, 2003, p.142). All these various levels, however, have a definite aim: they tend to canalize audience reaction. This is exactly why many believe that the culture industry's products are producing or reproducing the ideas and characteristics that are closely matched with the interests of capitalist society.

Of course the characteristics discussed are not restricted to TV and Adorno sees them as compromising of all other forms of mass media and mass cultural agents. Literature is one of the areas in which capitalist ideologies have pierced through and are being publicized. It is because of the vast reading public from which the popular novels, popular stories and poems enjoy that these ideologies can be very influential and of great importance in creating obedient, submissive individuals who believe in the principles of the capitalism by heart.

Having Adorno's discussions in mind, we can apply them to the play in discussion to prove our claim. As was just said, the message which is dominant in popular art and culture is that of adjustment and obedience. We can see this message to be publicized by Death of a Salesman, though it is hidden from the ordinary reader at first sight. Willy is shown as a character who opposes the values of his society when he finds out about their shallowness but, put under pressure by the society, he learns at the end that he has to consent. The reward of his consent is 20000 dollars that would go to his son, much more than what he could earn in life. Then he is contrasted with Charley and Bernard, who are successful in the society because they know the rules and laws of society by heart. We see for example Bernard who is a very good student in terms of the rules and laws of the school, and as a result gets into the university and is now a very successful lawyer. His opposite is Biff who is not behaving so well in terms of school laws; he cheats at the exams, defies the authorities, steals things and at the end is not allowed to go to university. Though an athlete, he ends up in jail and is now a lost man, not knowing what to do with himself.

Though when they were young Biff was very athletic and promising in sports and Bernard was weak and pale, we see ironically that now it is Bernard who is the most athletic of all by having tennis rackets and playing in a real tennis court. He has also a wife and two children and seems well established. The message that the reader learns beside everything else is that by consenting and following the rules you can achieve everything and that those who do not consent are the ones that are capable of cheating, theft and adultery, and who will end up as failures in life, since all that is presented to us by such unconsenting characters like Lomans is nothing but these. Other characters like Ben and Howard are also successful by putting aside their own ideals and romantic dreams. What is promoted by the characters of these two is the idea that hard work or "being well liked" has nothing to do with success. We see that Howard has got the company and all he has through inheritance and that Ben has got them by chance. We read that Ben wanted to go north to Alaska to find gold, but as he says "at that age I had a very faulty view of geography...I discovered after a few days that I was due sought, so instead of Alaska, I ended up in Africa..."(Perrine, 1974 p.1416). And we know that this unbelievable mistake has caused him to end up in diamond mines instead of gold mines! In this way the play seems to be a shrewd way of adjustment by saying that you cannot change your fate and what is waiting for you. You have only to conform to the society's conditions and only hope that your fate will bring you the money and success through luck, inheritance or any other way unforeseen by you and nothing like hard work, or trying different jobs or having great ideals would be necessary. Biff is another good example here. As soon as he puts aside his ideals, accepts his nothingness and declares his worthlessness his fate brings him a fortune of 20000 dollars from his fathers' life insurance.

To put aside the romantic dreams and be realistic is a message that Adorno believes mass culture and art gives to the reader. Willy's dreams lead him nowhere and Charley who is himself realistic tries to make him understand that his dreams won't really work; something which other characters like Howard, Ben and Bernard have accepted and Willy finally accepts. Conflicts in mass art are sham and at the end of each there is no winner but the society and man is only the victim of the powerful society against which he has revolted. There is nothing that man can do in this society and all 
his actions are directed and manipulated by forces of society which make him a mere puppet at its hands. Willy is such a character to my view. I believe Willy to be a consenting victim from the beginning and at the end. What he learns and teaches the reader is the lesson of conformity and adjustment by putting behind the romantic and individual ideals and dreams.

This play is an instance of "pseudo-criticism" as termed by Adorno. This is a term coined by him to refer to those works of the culture industry that claim to be critical of the society. Adorno believes that the so called critical works of the culture industry actually heighten the lie of individuality and defeat any such critical purpose as a consequence. To make the point clear he gives as an example the case of a radical film director who whishes to show the darker aspects of a merger between two corporations. "Even if the dominant figures are revealed as monstrous, their monstrousness would still be sanctioned as a quality of individual human beings that would obscure the monstrousness of the system whose servile functionaries they are" (Bernstein, 1996, p. 57). As it is clear, Adorno believes that works of mass culture treat all the actions, behaviors and characteristics of the characters as personal and individual traits which belong to a specific person and in this way make that character or person worthy of blame, showing the society to have nothing to do with these faults. In Death of the Salesman this is the case. As was discussed we get more and more involved with the personal world of Willy Loman, his thoughts, past life and his feeling of sin with the help of flash backs and the expressionism technique, so that we blame him and cannot see anyone else as responsible for his miseries. This point is emphasized by the fact that even Miller first chose "Inside His Head" as the title of the play (Miller, 1967, p.50). All that has been said so far about the play with the use of Adorno's theories brings to mind Marx's idea about the implicit and explicit messages of a play which were discussed at the beginning of this paper. But actually we see that in the case of Miller, his play's explicit social message is against the bourgeois ethics and beliefs and seems to criticize them while what it actually reveals is an approval of them and a confirmation of the capitalistic kind of society.

An important and final issue to be discussed would be the issue of cliché characters and their role in the play. Among the most important of them are the women characters in the play. It is easy to be disturbed by the apparently passive female stereotypes we find in Death of a Salesman. Women have been either marginalized and appear as loyal wives like Linda, or easy women (like The woman, Miss Forsythe, and Letta), or they have been hardly featured at all, such as Willy's mother, or Charley's wife. Women of Linda's generation were thought to be dependent on their men, stay at home and raise their children. As Abbotson states, in the time of World War Two many women were called to perform jobs outside home which were previously considered unsuitable for them and which gave them new authority and ambition. Some of these women were reluctant to pass this authority back to the men on their return from the army. The "working girl" was becoming a social reality by which many felt threatened (Abbotson, 2000, pp.53-55). To diminish such a treat these women were often dishonored and belittled wherever and however possible, largely to affirm old fashioned opinions of Bourgeois society about what was right and proper for men and women to do. Having this in mind, it should be pointed that there are a number of examples of working women in the play, such as The Woman, Jenny, and Miss Forsythe, and it is interesting to note how they are presented. Women like The Woman, Miss Forsythe and Letta are characterized in a way as being close to whores, as they are very easy with their "favors". One sided characters, as they are, they become the scapegoat for men's bad behavior, and are unable to defend themselves or have any opportunity to tell us how they feel. The Woman is shown to be the cause of alienation of Willy and his son Biff. Other single girls like Miss Forsythe or Letta, have the same power to divide men, as they take Happ and Biff away from their father. Even a good wife and mother like Linda is not shown as pure of any guilt, because we see Linda encouraging Willy to stay in New York and does not allow him to go with Ben to Alaska. In this way she ruins the chances that Willy had for achieving success and becoming rich. In a way women in this play are all like Eve who tempted Adam to commit sin and caused his downfall. This kind of cliché characterization is a characteristic of popular art, according to Adorno, or Bourgeois art according to Brecht, and one which makes identifying Death of a Salesman as a high social play more difficult and objectionable.

\section{CONCLUSION}

Summing up all that has been said so far we can say that to achieve a conclusion about Miller and his play Death of a Salesman regarding the social issues and social criticism would be difficult and a challenging task. This play has different aspects each of which either proves or disapproves the categorization of the play as a social one. But one thing is clear and that is, Miller to my view never tried and wanted to put all the blames on the society, to show it as an evil that must be overcome. He believes in society and does not rule it out though he sees some flaws in it. However it must also be said that to reach a more reliable answer in this regard, studying of a single play of a writer like Miller would not be satisfactory enough and a more complete and thorough study which would include a number of Miller's other plays would be necessary. We should also have in mind that despite all the criticisms, Miller is one of the greatest and most influential playwrights of his time in America and all around the world, someone whose plays are performed long after they have been written with the same or even greater enthusiasm shown by the audiences when the plays were first appeared on the stage. And Finally I would like to add that whatever Miller's weaknesses or faults are, Death of a Salesman has many beauties and merits that to have written it is an achievement of such a great significance that would make us allow Arthur Miller a slip or even a fall. 


\section{REFERENCES}

[1] Abbotson, Susan C.W. (2000). Student Companion to Arthur Miller. New York: Green Wood P.

[2] Bernstein, J. M., ed. (1996). The Culture Industry: Selected Essays on Mass Culture. London: Routledge.

[3] Brown, John Russel, and Bernard Harris, eds. (1975). American Theater: Stratford-Upon Avon Studies. 1967. London: Edward Arnold.

[4] Corrigan, Robert W. (1969). Arthur Miller: A Collection of Critical Essays. New Jersey: Prentice Hall.

[5] Carson, Noel. (1982). Arthur Miller: Macmillan Modern Dramatists. London: Macmillan.

[6] Downer, Allen S, (ed). (1967). American Drama and its Critics: A Collection of Critical Essays. University of Chicago Press.

[7] Downer, Allen S. (ed). (1974). The American Theater: Voice of America Forum Lectures 1967. New Jersey: Princeton Hall.

[8] Eagleton, Terry. (2001). Marxism and Literary Criticism. London: Routledge.

[9] Finkelstein, Sidney. (1967). Existentialism and Alienation in American Literature. 1965. New York: International Publishers.

[10] Gassner, John. (1954). Masters of Drama. ( $3^{\text {rd }}$ edn). New York: Dover.

[11] Lewis, Allen. (1970). American Plays and Playwrights of the Contemporary Theater. Rev. edn. New York: Crown Publishers.

[12] Lumley, Fredric. (1967). New Trends in the Twentieth Century Drama. London: Lumley.

[13] Miller, Arthur. (1967). Collected Plays. New York: The Viking Press.

[14] Perrine, Laurence. (1974). Literature: Structure, Sound and Sense. (2 ${ }^{\text {nd }}$ edn). USA: Harcourt Brace.

[15] Williams, Raymond. (1971). Drama: From Ibsen to Brecht. London: Chatto and Windus.

[16] Witkin, Robert W. (2003). Adorno on Popular Culture. London: Routledge.

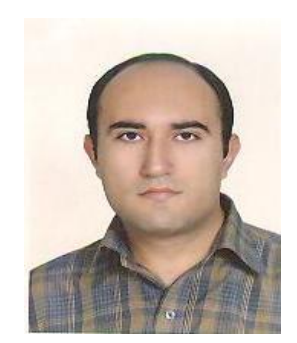

Kaveh Khodambashi Emami is a lecturer of English Literature at the Isfahan University of Technology and a guest lecturer at the University of Isfahan. He holds an M.A in English Literature from Allameh Tabatabai University (2005) and his B.A in English Literature from Isfahan University (2002). He presently offers graduate courses in Literary criticism, Novel, Literary History, Drama and Poetry. His main interests are Literary Criticism and Modern European and American Drama. 